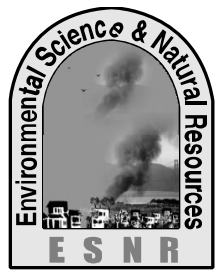

\title{
Effect of Shrimp Processing Waste Feed on the Growth Performance of Prawn (Macrobrachium rosenbergii) in Aquarium and Pond Condition
}

\author{
F. H. Shikha, M. I. Hossain ${ }^{*}$ and A. D. Sharma \\ Department of Fisheries Technology, Bangladesh Agricultural University, Mymensingh-2202, \\ Bangladesh \\ *Corresponding author : ihossain.ft@bau.edu.bd
}

\begin{abstract}
The study was conducted to assess the effect of formulated feed on the growth performance of prawn both in aquarium and pond system during 25 September to 25 December 2013. The feeds/diets were, diet 1 (formulated feed), diet 2 (commercial feed), diet 3 (custard cake) and diet 4 (shuji-ata ball). Protein percent of the feeds were $34.51 \%$ in Diet-1, $32.67 \%$ in Diet-2, $25.41 \%$ in Diet-3 and $21.43 \%$ in Diet 4 . Four experimental diets were assigned to four treatments viz. T1, T2, T3 and T4 both in aquarium and pond. The water quality parameters were monitored 15 days interval and the ranges were: temperature $26^{\circ} \mathrm{C}$ to $29.8^{\circ} \mathrm{C}$ (aquarium system) and $24.5^{\circ} \mathrm{C}$ to $29.9^{\circ} \mathrm{C}$ (pond system) ; $\mathrm{pH} 7.07$ to 8.09 (aquarium system) and 7.87 to 8.45 (pond system); DO 7.07 to 8.09 (aquarium system) and 5.08 to $5.86 \mathrm{mg} / \mathrm{L}$ (pond system). The result of the present study showed that Prawn feed Diet 1 and Diet 2 resulted highest weight gain 2.42 and $2.39 \mathrm{~g}$ (aquarium system) and 3.63 and $3.5 \mathrm{~g}$ (pond system), respectively. Based on the result of present study, it could be suggested that shrimp waste can be replaced in the diets of prawn (Macrobrachium rosenbergii) along with other ingredients.
\end{abstract}

Key words: Aquarium, Shrimp processing waste feed, Growth performance, Pond, Prawn (Macrobrachium rosenbergii)

\section{Introduction}

Previous studies revealed that most of the shrimp processing waste discarded in dumping yard and some are sold. The system of shrimp processing waste outside the industries causes a serious environmental pollution occupying a large area. The industries managed the waste product only if it could be sold. Shrimp wastes have four major component protein, lipid, carbohydrates and moisture. Composition analysis indicates that in shrimp flesh about $19-21 \%$ protein, 0.6-1.2\% lipid, 1-2\% carbohydrates, 74-77\% water and 1.2-1.6\% ash (Moor and Eitenmiler, 1980). Shrimp waste can be utilized for the production of fish or prawn feed. This may include among others development of a nutritionally balanced aqua feed, extraction of various pigments such as astaxanthin, production of chitin and chitosan, extraction of enzymes, development of value added food products such as shrimp sauce, shrimp paste, shrimp powder and so on. Developing a feed that is nutritionally adequate and cost effective is not an easy practice and the formulation will vary country to country as both prices and consumer preferences. The first restriction is that feed ingredient availability then cost and quality variation between regions. In most cases reducing the use of fish meal and replacing it with soybean meal and corn or wheat gluten (which provide a better balance of amino acids) often improve effectiveness. Once a quality feed is processed, stabilized and packed it is of little value if it is not properly applied. Proper application of feeds is not an easy task and it goes hand in hand with proper stocking procedures, regular sampling for growth and health as well as the maintenance of suitable water quality parameters. Improving the economic return from the feed should be one of the primary goals of the farm manager, although it is far from an easy task. Feed input must be adjusted for the nutrient density of the diet; that is to say if we have higher concentrations of a nutrient in the feed we would offer less feed. It is necessary to realign the processing equipment to not only produce quality feeds but also reduce energy used at the mill. At the farm it is also necessary to evaluate critically water quality and feed management to obtain the best return on our investments in feed. Prawn, like all animals, must consume energy to maintain normal activities before they can invest it in growth. Consequently, adequate energy intake is critical to survival and growth. Fortunately, when commercial feeds are formulated to meet dietary protein requirements and maintain adequately levels of carbohydrates for proper pellet stability, they are not likely to be extremely low in energy. Prawn do not require a specific type of protein like fishmeal, but do require a source of non-specific nitrogen and essential amino acids. The minimum amount of dietary protein required producing acceptable growth and survival have been determined for a number of species. The levels of metabolites in pond water that can have an 
adverse effect on growth are generally an order of magnitude lower than those tolerated by prawn for survival. Good water quality is characterized by adequate microorganism such as bacteria produce metabolites in a pond. The major source of nutrients in aquaculture is the feed. In semi intensive culture system, prawn are more sensitive to temperature than in the extensive one because of the higher biomass and less water volume. Oxygen is one environmental parameter that exerts a tremendous effect on growth and production through its direct effect on feed consumption and metabolism and its direct effect on environmental condition. There is a strong relationship between the quality of the water in the pond and that in the water-surrounding environment. Like all animals, prawn requires proteins, lipids, energy source, vitamins, minerals, oxygen and water for survival and growth. Considering above mentioned points the study was designed to formulate diet for prawn with shrimp processing industry waste in replacement of fish meal and to observe the growth performance of prawn by in taking the diet prepared with the shrimp processing waste both in aquarium and pond system.

\section{Materials and Methods}

Formulation and preparation of feed Collection of feed ingredients

Shrimp head and shell were collected from the processing plants of Khulna and Chittagong. The other ingredients such as- rice bran, wheat bran, soybean meal, maize, molasses, milk powder, egg, shuji, ata (wheat flour), and vitamin mineral premixes were collected from local markets of Mymensingh.

\section{Feed formulation and preparation}

In this experiment to observe the growth performance of prawn by in taking formulated feeds three different diets were prepared in the laboratory (Diet-1: Formulated feed with shrimp processing waste, Diet-3: Custard and Diet-4: Shuji-ata ball) accept Diet-2. Commercial diet was used as Diet-2. Here, Diet-1 (prepared with shrimp processing waste) was prepared using shrimp processing waste along with other ingredients (Table 1). All the collected ingredients were ground finely and sieved to pass through small mesh. The ingredients were mixed properly and made into dough and finally made into pellets using a pellet machine. The pellets were dried in oven at $45^{\circ} \mathrm{C}$. The pellets were allowed to cool in the air, packed in airtight polythene packs. The detailed methodology is shown in Flow diagram-1. Diet- 2, the commercial one was purchased from the local market. In case of Diet-3 each ingredient (appropriate amount of each according to the calculation, Table 1) were taken in a clean pot, blended homogeneously. Then Blended ingredients were poured on a tray, floated the tray on boiling water in a big pot for 25-30 minutes and the tray was taken out from big pot and left for cooling. After cooling the custard cake was cut into pieces, kept in glass bottle and stored at $-18^{\circ} \mathrm{C}$ to $-20^{\circ} \mathrm{C}$ until further use. For preparing Diet-4, each ingredient (appropriate amount of each according to the calculation, Table 1) were taken in a clean pot then mixed homogeneously. Boiled water was then added a little by little to the ingredients of the pot and prepared ball by hand. ShujiAtta balls were then dried in sunlight. After bringing the shuji-ata balls from sunlight, left for cooling. After cooling the shuji-ata balls were put into glass bottle and stored at $-18^{\circ} \mathrm{C}$ to $-20^{\circ} \mathrm{C}$ until further use. Plate- 1 shows the photographs of all four (4) diets after preparation. 
Table 1. Formulation of Diet-1 (Formulated feed with shrimp waste), Diet-2, Diet-3 and Diet-4

\begin{tabular}{|c|c|c|c|c|}
\hline \multirow[t]{2}{*}{ Feed ingredient } & \multicolumn{4}{|c|}{ Ingredients (\%) } \\
\hline & Diet-1 & Diet-2 & Diet-3 & Diet-4 \\
\hline Shrimp waste & 35.00 & & & \\
\hline Egg & & & 2 piece & \\
\hline Powder milk & & & 20.00 & \\
\hline Wheat flour & & & 20.00 & 49.00 \\
\hline Rice bran & 20.00 & 28.00 & & \\
\hline Shuji & & & & 49.00 \\
\hline Wheat bran & 10.00 & 28.00 & & \\
\hline Mustard oil cake & & 12.00 & & \\
\hline Coconut oil cake & & 8.00 & & \\
\hline $\begin{array}{l}\text { Soybean / Palm oil } \\
\text { cake }\end{array}$ & & 4.00 & & \\
\hline Fish powder & & 1.00 & & \\
\hline Meat bone & & 1.00 & & \\
\hline Snail powder & & 1.20 & & \\
\hline Oil (Soybean/ Palm) & & 0.80 & 0.8 & \\
\hline Maize & 14.00 & & & \\
\hline Soybean meal & 15.00 & & & \\
\hline Molasses & 4.00 & & & \\
\hline Yeast & & & 0.1 & \\
\hline Sugar & & & 1.2 & \\
\hline Binder & & 16.0 & & \\
\hline $\begin{array}{l}\text { Vitamin \& mineral } \\
\text { mix }\end{array}$ & 1.00 & 1 tablet & & 1 \\
\hline Multivitamin capsule & & & 2 capsule & \\
\hline Salt & 1.00 & & & 1 \\
\hline Total & 100.00 & 100.00 & 100.00 & 100.00 \\
\hline
\end{tabular}

Ingredients were grinded finely

Each ingredient (appropriate amount of each according to the calculation) were

taken in a clean big bowl

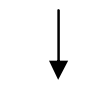

Mixed well

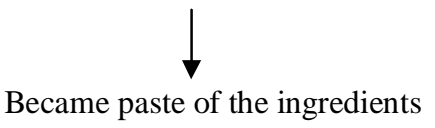

Became paste of the

Water was added to the mix a little by little

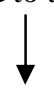

Pellets were made by pellet machine of desired size

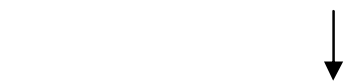

Pellets were dried and stored in airtight polythene pack

Flow Chart 1. Protocol for preparation of Diet-1 (with shrimp processing waste) 

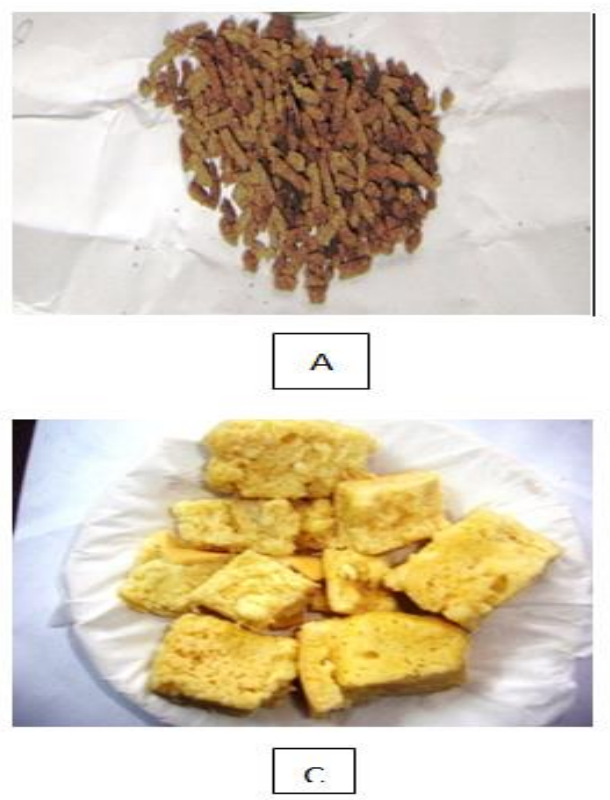

Plate 1. Four experimental diets used (A) Diet-1, (B) Diet-2, (C) Diet-3, (D) Diet-4 used in the experiment
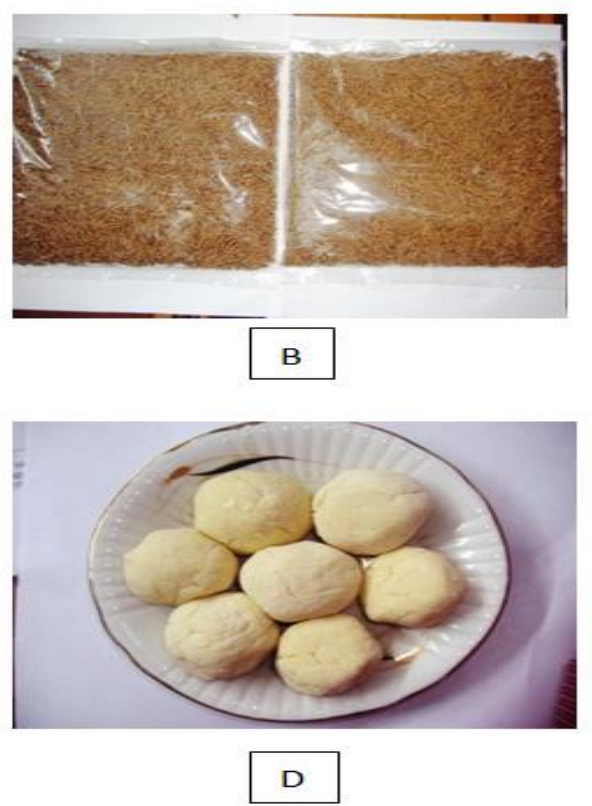

\section{Analytical methods}

Proximate composition, fiber of prepared feeds and individual ingredients were analyzed in the Processing Laboratory of the Department of Fisheries Technology, BAU following the Association of official Analytical Chemists methods (2005) with slight modifications.

\section{Data analysis}

Data obtained from the present study were analyzed statistically to observe growth performance of different fish species. Data was entered into the Excel and then simple statistics such as mean and standard Deviation (SD) of growth parameters of the fishes was find-out statistically.

\section{Growth performance of prawn Experimental site}

The experiment was conducted in 8 experimental ponds and 8 glass aquaria. The pond was situated behind the Faculty of Fisheries and aquarium was located on wet laboratory at Department of Fisheries Technology in the Faculty of Fisheries, Bangladesh Agriculture University (BAU), Mymensingh, for a period of 60 days commencing from 25 October to 25 December, 2013.

\section{Experimental system}

All the rearing and stocking activities were carried out in two systems, one aquarium and another pond system maintain in the Department of Fisheries Technology. The entire aquariums were kept on $1 \mathrm{~m}$ high table to facilitate better observation and accessibility. For convenience the tanks were numbered as 1,2, and 3 up to 8 . The ponds were equal in size and similar in shape, depth, basin, configuration and pattern type including water supply facilities. The size of each pond is $30 \mathrm{~m}^{2}$. The water depth was maintained to a maximum of 1.2 $\mathrm{m}$ above the pond bottom. There is well organized inflow and outflow system to maintain the water level. Leaves of coconut tree were used in each pond to provide shelter for prawn. The ponds were surrounded by fine meshed nylon nets to prevent the escape of prawns by walking. Oxygen tablets were used to enrich the oxygen in the experimental ponds in rainy days. To keep the good water quality in the ponds water were exchanged at regular intervals using water from a deep tube well.

\section{Pond preparation}

Pond preparation is a pre-requisite for successful fish culture. To achieve the goal of culture of prawn in ponds, the experimental ponds were prepared precisely. The ponds dried before stocking fry. Pond water pumped out and then the ponds were exposed to sunlight for about 2 weeks. Ponds dykes and bottom repaired where necessary. The excessive bottom mud was removed from the pond. Liming was done at the rate of $0.5 \mathrm{~kg} /$ decimal. After 7 days of liming experimental ponds were filled up with water up to 4 feet with shallow water pump machine that was propelled by e

\section{Aquarium preparation}

The proposed research work was undertaken in 08 glass aquaria (each contains 30L) at the wet laboratory under the Department of Fisheries Technology, BAU (Plate-2.b). At first any leakage of each aquarium was 
checked up. The aquaria were cleaned with the help of detergent and were sponged thoroughly and water was scooped out from the aquaria. The aquaria were rewashed and filled almost up to the top level and kept for a day. The water of the aquaria was scooped out in the following day. The aquaria were again washed with the help of common salt to destroy the microorganisms or other harmful elements. Then the aquaria were sponged and were filled with tap water and scooped out and then dried. An adequate level of dissolved oxygen, in each aquarium was maintained through artificial aeration during the experimental period. All the aquariums were kept on $1 \mathrm{~m}$ high wooden table to facilitate better observation and accessibility. For convenience the tanks were numbered as 1, 2, 3 up to 08 .

\section{Experimental design}

The experiment was conducted in completely randomize design. To study the growth of Macrobrachium rosenbergii and water quality parameters, four experimental diets were assigned to four different treatments viz. T1, T2, T3 and T4 for aquarium and pond which has one replication. In this experiment Diet-1 (prepared with shrimp waste), Diet2, Commercial feed, Diet-3 Custard and Diet-4 Shujiata ball were used for the treatment 1, 2, 3 and 4, respectively. The Macrobrachium rosenbergii fry was randomly distributed at a rate of 50 fish each pond and $10-12$ in each aquarium. Feeding was done twice daily at $9.00 \mathrm{am}$ and $5.00 \mathrm{pm}$. Prawn were fed at the rate of $10 \%$ of body weight at the beginning. The feeds were dispersed by hand broadcasting over the water.

\section{Experimental prawn}

The uniform sized PL-30 of Macrobrachium rosenbergii were collected from the Fresh Water Station, Bangladesh Research Institute (BFRI), Mymensingh.

\section{Acclimatization of prawn in the laboratory}

The PL-30 was kept in a number of aquaria in the laboratory for 7 days to acclimatize with the new environment and also with the experimental feed. The PL-30 was fed with custard cake containing $25.41 \%$ protein.

\section{Stocking of prawn}

The PL-30 was stocked at the rate of 50-55 and 10-12 (PL-30) in T1, T2, T3 and T4, respectively in both aquarium and pond system. Before releasing the fish fry (PL-30) in the aquarium the initial weight was measured.

\section{Feeding rates}

The feed was supplied daily at the rate of $10 \%$ of the body weight of reared PL-30 in all aquaria and ponds and sampling was done regularly at an interval of 15 days. The amount of supplemental feed administered was adjusted on regular basis. The PL-30 was fed twice daily, half of the ration in the morning between 9:00 to 10.00 a.m. and another half in the afternoon between 4:00 to 5:00 p.m.

\section{Sampling and analytical techniques Sampling of prawn}

Fortnightly sampling was done by using a cast net to observe the growth of prawn and to adjust the feeding rate. Growth of prawn in the sampling was measured by using a digital electronic balance (OHAUS, Model CT 1200-S, USA). General pond condition and fish health condition were monitored regularly during the culture period. The sampled prawns were handled very carefully as the species are very susceptible to handling stress.

\section{Physico-chemical parameters}

Some important physic-chemical parameters of pond and aquarium water such as temperature, $\mathrm{pH}$ and dissolved oxygen were measured and recorded fortnightly throughout the experimental period.

\section{Water temperature $\left({ }^{\circ} \mathrm{C}\right)$}

The temperature (0C) of aquarium and pond water was recorded with the help of a Thermometer (YSL, Model 58, made in USA) between 9:00 to 10:00 a.m.

\section{Dissolved oxygen ( $\mathrm{mg} / \mathrm{L})$}

To determine dissolve oxygen of water samples were collected in black glass bottles with care to avoid any air bubble and immediately brought to the water quality laboratory and dissolved oxygen was measured by a DO meter (YSL, Model 58, USA) between 9:00 to $10: 00$ a.m.

\section{Survival rate (\%)}

In each treatment survival rate of fry was estimated on the basis of number of fish remained at the end of the experiment in relation to the number stocked. Survival rate of fish was calculated by counting the actual number of fish survived divided by initial number of stocked fish and multiplying by 100 . So the equation of survival rate is:

$$
\text { Survival rate }(\%)=\frac{\text { Total number of fish harvested }}{\text { Total number of fish stocked }} \times 100
$$

\section{Data analysis}

Data obtained from the present study were analyzed statistically to observe growth performance of different fish species. Data were entered into the Excel and then simple statistics such as mean and standard Deviation (SD) of growth parameters of the fishes were find-out statistically. 


\section{Results and Discussion}

\section{Proximate composition of diets}

The proximate composition of different experimental diets including the control is shown in Fig. 1. In the experimental diets the moisture content obtained $10.12 \%, 10.65 \%, 16.42 \%$ and $12.59 \%$, respectively. The percent moisture content in feeds did not vary significantly among the diets. There were variations in protein, lipid, ash and crude fiber content of different diets. The mean crude protein value of Diet 1, Diet 2, Diet 3 and Diet 4 was found $34.51 \%, 32.67 \%, 25.41 \%$ and $21.43 \%$, respectively. The analyzed crude protein contents of fish feed varied from $21.43 \%$ to $34.51 \%$. There is significant difference in crude protein in feed. Protein is the major growth promoting factor in feed.

The protein requirement of fish is influenced by various factors such as fish size, water temperature, feeding rate, availability and quality of natural foods. Shrimp feed diet containing $25 \%, 35 \%$ and $45 \%$ crude protein showed no differences in weight gain (Aranykananda and Lawrence, 1993). Cousin et al. (1991) evaluated weight gain of L. vannamei fed diets in which crude protein ranged from $18 \%$ to $34 \%$.

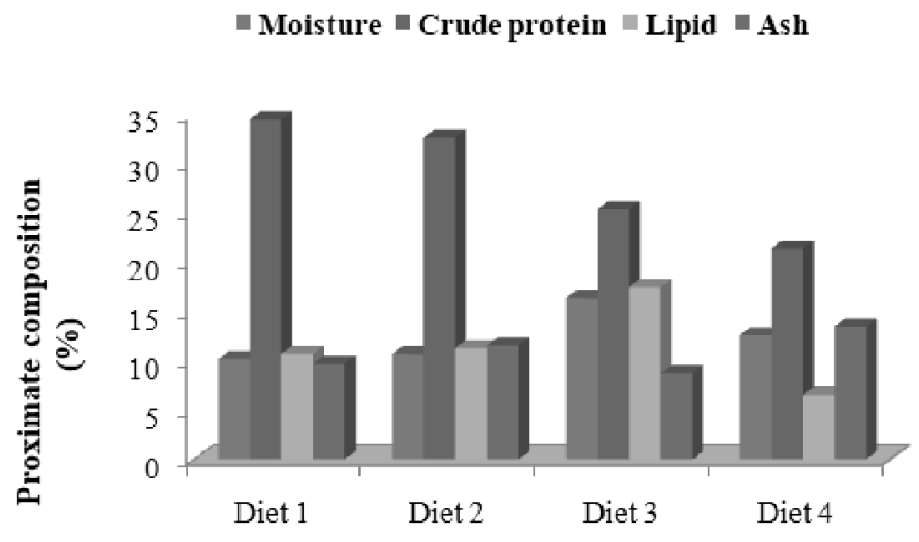

Types of diets

Fig. 1. Proximate composition of different diets

The mean crude lipid value of Diet 1, Diet 2, Diet 3 and Diet 4 obtained 10.66\%, 11.24\%, $17.51 \%$ and $6.53 \%$, respectively. The analyzed crude lipid contents of feed varied from 6.53 to $17.51 \%$. Sheen and Chen (1992) reported that $P$. monodon fed diet containing $8 \%, 10 \%$, or $12 \%$ cod liver oil mixture had significantly higher weight gain than those fed lower lipid levels.

The mean ash content of Diet 1, Diet 2, Diet 3 and Diet 4 were found $9.65 \%, 11.52 \%, 8.72 \%$ and $13.52 \%$, respectively. The analyzed ash contents of feed varied from $8.72 \%$ to $13.52 \%$. Kanazawa et al. (1984) reported that diets containing $11.02 \%$ ash improved growth of $P$. japonicus compared with diet containing lower ash content. The proximate composition of different diets obtained in this study re more or less similar to the findings of other researchers.

\section{Water quality parameters}

The water quality parameter such as water temperature, $\mathrm{pH}$, and dissolved oxygen content of both aquarium and pond system in all the treatments were monitored fortnightly during the experimental period. Monthly variation in the ranges and mean value of these parameters in different treatments are shown in Table 2 and Table 3.

\section{Water temperature $\left({ }^{0} \mathrm{C}\right)$}

During the study period the mean value of the temperature measured in different treatments in aquarium system varied $26^{\circ} \mathrm{C}$ to $29.8^{\circ} \mathrm{C}$ (Table 2).

The overall mean value of the temperature measured in aquarium system during the study period was $27.06 \pm 1.48$. The maximum temperature $\left(29.8^{\circ} \mathrm{C}\right)$ was recorded in November in $\mathrm{T} 1$ and the minimum value $\left(26^{\circ} \mathrm{C}\right)$ was observed in December in T3. In pond system, the temperature measured in different treatments varied from $24.5^{\circ} \mathrm{C}$ to $29.9^{\circ} \mathrm{C}$ (Table 3). The overall mean value of the temperature measured during the study period was $28.16 \pm 1.38$ in pond system. The maximum temperature $\left(29.9^{\circ} \mathrm{C}\right)$ was recorded in November in $\mathrm{T} 1$ and the minimum value $\left(24^{\circ} \mathrm{C}\right)$ was found in December in $\mathrm{T} 2$ in pond system. 
Temperature plays a significant role in respect of fish production. Fish and prawn have the same temperature tolerance and it is supposed that prawn also has similar optimum temperature requirements as fish.

The water temperature recorded in both systems was slightly lower than the recommended suitable temperature $\left(21.9^{\circ} \mathrm{C}\right.$ to $\left.33.5^{\circ} \mathrm{C}\right)$ for shrimp culture (Fair, 1981). Hoq et al. (1996) reported that water temperature ranged from 27.5 to $30.5^{\circ} \mathrm{C}$ was suitable for the growth of Galda chingri (M. rosenbergii).
Maclean et al. (1994) reported that water temperature ranged from 28.9 to $29.1^{\circ} \mathrm{C}$ for the culture of freshwater prawn in earthen ponds. Hossain et al. (2000) measured the water temperature in 12 experimental ponds at Bangladesh Agriculture University campus, Mymensingh, which varied between 28.7 and $31.5^{\circ} \mathrm{C}$ for the culture of freshwater $M$. rosenbergii. The result of the above mentioned studies more or less agreed with the result of present study.

Table 2. Monthly variation in the ranges and mean value of different water quality parameters in different treatments (in aquarium system) during the study period

\begin{tabular}{clcccc}
\hline Parameter & Months & $\mathbf{T}_{\mathbf{1}}$ & $\mathbf{T}_{\mathbf{2}}$ & $\mathbf{T}_{\mathbf{3}}$ & $\mathbf{T}_{\mathbf{4}}$ \\
\hline Temperature & October & $28.8-29.5$ & $27.9-29.4$ & $29.4-29.5$ & $29-29.8$ \\
$\left({ }^{0} \mathrm{C}\right)$ & & $(29.1 \pm 0.29)$ & $(28.9 \pm 0.68)$ & $(29.5 \pm 0.17)$ & $(29.3 \pm 0.35)$ \\
& \multirow{2}{*}{ November } & $28.4-29$ & $28.3-29$ & $28.5-29.5$ & $28.5-29$ \\
& & $(28.6 \pm 0.27)$ & $(28.6 \pm 0.35)$ & $(29.0 \pm 0.42)$ & $(28.8 \pm 0.20)$ \\
& December & $26-26.5$ & $26.1-26.4$ & $26-26.5$ & $26.5-27.1$ \\
& & $(26.25 \pm 0.23)$ & $(26.2 \pm 0.12)$ & $(26.8 \pm 0.26)$ & $(26.9 \pm 0.26)$ \\
Dissolved & October & $5.9-7.0$ & $5.3-5.57$ & $5.5-7.0$ & $5.3-6.2$ \\
oxygen (DO, & November & $(6.32 \pm 0.53)$ & $(5.52 \pm 0.17)$ & $(6.02 \pm 0.67)$ & $(5.75 \pm 0.42)$ \\
mg/L) & & $5.3-6.5$ & $5.6-6.3$ & $5.3-6.0$ & $5.3-6.2$ \\
& \multirow{2}{*}{ December } & $(5.75 \pm 0.52)$ & $(5.95 \pm 0.35)$ & $(5.57 \pm 0.29)$ & $(5.87 \pm 0.39)$ \\
& & $5.0-6.2$ & $5.5-6.5$ & $5.1-5.6$ & $5.7-6.3$ \\
pH & $(5.42 \pm 0.53)$ & $(6.0 \pm 0.40)$ & $(5.30 \pm 0.21)$ & $(5.97 \pm 0.25)$ \\
& October & $7.90-7.97$ & $7.23-7.95$ & $7.09-7.97$ & $7.44-7.89$ \\
& & $(7.99 \pm 0.08)$ & $(7.57 \pm 0.23)$ & $(7.56 \pm 0.36)$ & $(7.62 \pm 0.19)$ \\
& \multirow{2}{*}{ November } & $7.50-7.98$ & $7.76-8.09$ & $7.56-7.90$ & $7.67-8.03$ \\
& & $(7.79 \pm 0.21)$ & $(7.92 \pm 0.14)$ & $(7.78 \pm 0.16)$ & $(7.90 \pm 0.16)$ \\
& \multirow{2}{*}{ December } & $7.07-8.09$ & $7.44-7.84$ & $7.23-8.06$ & $7.23-8.08$ \\
& & $(7.77 \pm 0.47)$ & $(7.67 \pm 0.19)$ & $(7.68 \pm 0.34)$ & $(7.67 \pm 0.37)$ \\
\hline
\end{tabular}

(*Figure in the parentheses indicates mean values \pm standard deviation) 
Table 3. Monthly variation in the ranges and mean value of different water quality parameters in different treatments (in pond system) during the study period

\begin{tabular}{clllll}
\hline Parameter & \multicolumn{1}{c}{ Months } & \multicolumn{1}{c}{$\mathbf{T}_{\mathbf{1}}$} & \multicolumn{1}{c}{$\mathbf{T}_{\mathbf{2}}$} & \multicolumn{1}{c}{$\mathbf{T}_{\mathbf{3}}$} & \multicolumn{1}{c}{$\mathbf{T}_{\mathbf{4}}$} \\
\hline Temperature & October & $27.9-28.5$ & $27.9-28.5$ & $27.5-28.5$ & $27.5-28.1$ \\
$\left({ }^{\mathbf{C}} \mathbf{C}\right)$ & & $(28.2 \pm 0.35)$ & $(28.2 \pm 0.28)$ & $(28 \pm 0.45)$ & $(27.8 \pm 0.28)$ \\
& \multirow{2}{*}{ November } & $27.1-29.9$ & $27.1-28.5$ & $27.6-28.4$ & $27.5-28.1$ \\
& & $(28.5 \pm 0.38)$ & $(27.8 \pm 0.43)$ & $(28 \pm 0.34)$ & $(27.8 \pm 0.26)$ \\
& \multirow{2}{*}{ December } & $24.6-24.8$ & $24.5-27.7$ & $24.7-24.9$ & $24.9-25.0$ \\
& & $(24.7 \pm 0.10)$ & $(26.1 \pm 0.08)$ & $(24.8 \pm 0.08)$ & $(24.9 \pm 0.08)$ \\
Dissolved oxygen & October & $5.08-5.67$ & $5.23-5.54$ & $5.31-5.73$ & $5.25-5.74$ \\
$(\mathbf{D O}, \mathbf{m g} / \mathbf{L})$ & & $(5.27 \pm 0.23)$ & $(5.37 \pm 0.13)$ & $(5.58 \pm 0.18)$ & $(5.50 \pm 0.20)$ \\
& \multirow{2}{*}{ November } & $5.43-5.72$ & $5.31-5.76$ & $5.51-5.86$ & $5.23-5.67$ \\
& & $(5.58 \pm 0.13)$ & $(5.51 \pm 0.19)$ & $(5.59 \pm 0.34)$ & $(5.39 \pm 0.21)$ \\
& \multirow{2}{*}{ December } & $5.09-5.85$ & $5.09-5.73$ & $5.23-5.69$ & $5.33-5.75$ \\
& & $(5.52 \pm 0.34)$ & $(5.45 \pm 0.31)$ & $(5.43 \pm 0.19)$ & $(5.49 \pm 0.18)$ \\
& \multirow{2}{*}{ October } & $8.31-8.45$ & $7.87-8.22$ & $8.03-8.45$ & $7.95-8.31$ \\
& & $(8.37 \pm 0.06)$ & $(8.08 \pm 0.16)$ & $(8.25 \pm 0.17)$ & $(8.08 \pm 0.16)$ \\
& \multirow{2}{*}{ November } & $8.00-8.22$ & $8.00-8.32$ & $8.00-8.22$ & $7.91-8.32$ \\
& & $(8.18 \pm 0.13)$ & $(8.18 \pm 0.13)$ & $(8.08 \pm 0.09)$ & $(8.19 \pm 0.19)$ \\
& \multirow{2}{*}{ December } & $7.95-8.31$ & $7.95-8.31$ & $8.00-8.35$ & $8.00-8.40$ \\
& & $(8.08 \pm 0.16)$ & $(8.08 \pm 0.15)$ & $(8.19 \pm 0.14)$ & $(8.16 \pm 0.18)$ \\
\hline
\end{tabular}

(*Figure in the parentheses indicates mean values \pm standard deviation)

\section{Hydrogen ion concentration (pH)}

In aquarium system, the mean value of $\mathrm{pH}$ of the subsurface water in the experimental treatments varied from 7.07 to 8.09 (Table 2). The highest $\mathrm{pH}$ value 8.09 was observed in $\mathrm{T} 2$ in November and the lowest $\mathrm{pH}$ value of 7.07 in $\mathrm{T} 1$ on December. The overall mean $\mathrm{pH}$ value during the study period was $7.74 \pm 0.14$. The mean value of $\mathrm{pH}$ of the subsurface water in the experimental treatments in pond system varied from 7.87 to 8.45 (Table 3 ). The highest $\mathrm{pH}$ value was found 8.45 in $\mathrm{T} 1$ in October and the lowest $\mathrm{pH}$ value of 7.87 in $\mathrm{T} 2$ in October. The overall mean $\mathrm{pH}$ value during the study period was $8.16 \pm 0.08$. According to Swingle (1967) $\mathrm{pH}$ value ranging from 6.5 to 9.0 was suitable for pond fish culture. The $\mathrm{pH}$ value ranged from 7.5 to 8.5 was suitable for $M$. rosenbergii in earthen ponds (Jia-Mo et al., 1988a). Hoq et al. (1996) reported the rnge of $\mathrm{pH}$ from 7.6 to 8.0 in five prawn farmerô ponds. Hossain et al. (2000) reported that $\mathrm{pH}$ from 6.8 to 8.4 was suitable for $M$. rosenbergii. Mean $\mathrm{pH}$ value recorded in different months in different treatments in the present study were within the suitable range.

\section{Dissolved oxygen (mg/L)}

Dissolved oxygen (DO) was measured in the morning between 9.30 to10.00 am. During the experiment period the dissolved oxygen in the different treatments in aquarium system, varied from 5.0 to 7.0 (Table 2) and in pond system varied between 5.08 to $5.86 \mathrm{mg} / \mathrm{L}$ (Table 3). In pond system, the highest DO concentration $(5.86 \mathrm{mg} / \mathrm{L})$ was observed in $\mathrm{T} 3$ in November and the lowest DO concentration (5.08 $\mathrm{mg} / \mathrm{L}$ ) was in $\mathrm{T} 1$ in October.

Table 4. Growth and food utilization of prawn fed different experimental diet in aquarium system

\begin{tabular}{ccccc}
\hline Parameters & Diet 1 & Diet 2 & Diet 3 & Diet 4 \\
\hline Mean initial weight(g) & $1.26 \pm 0.14$ & $1.22 \pm 0.12$ & $1.27 \pm 0.34$ & $1.26 \pm 0.14$ \\
Mean final weight(g) & $3.68 \pm 0.07$ & $3.61 \pm 0.12$ & $3.21 \pm 0.20$ & $2.29 \pm 0.16$ \\
Weight gain (g) & $2.42 \pm 0.07$ & $2.39 \pm 0.12$ & $1.94 \pm 0.20$ & $1.03 \pm 0.16$ \\
\% Weight gain & 192.06 & 195.90 & 152.75 & 81.74 \\
SGR (\%) & 1.79 & 1.80 & 1.55 & 0.99 \\
Survival rate (\%) & $80 \%$ & $80 \%$ & $70 \%$ & $70 \%$ \\
\hline
\end{tabular}

(*Fig. in the parentheses indicates mean values \pm standard deviation) 
The overall mean DO value observed in the study

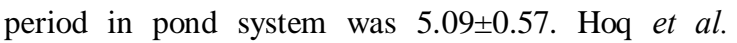
(1996) recorded DO ranging from 4.0 to $5.9 \mathrm{mg} / \mathrm{L}$ in five prawn farmerôs ponds which were suitable for fish culture. Jia-Mo et al. (1998a) reported the dissolved oxygen $4.5 \mathrm{mg} / \mathrm{L}$ where $M$. rosenbergii were cultured in earthen ponds. Jaruvat and Somnuk (1987) reported that shrimp would die if dissolved oxygen is less than $0.7 \mathrm{mg} / \mathrm{L}$. Hossain et al. (2000) reported the dissolved oxygen content of 3.0 to $6.1 \mathrm{mg} / \mathrm{L}$ in earthen ponds in $M$. rosenbergii monoculture. The result of the above studies coincides with the present study.

\section{Growth performance of prawn}

Growth performance of prawn in different treatments of aquarium and pond system in terms of initial weight gain, (\%) weight gain and survival rate $(\%)$ were calculated and are shown in Table 4 and Table 5.

\section{Weight gain}

The comparison of weight gain in prawn among the treatments in aquarium system is shown in Table 4 and Fig. 2. On the other hand this comparison of weight gain in pond system is shown in Table 5 and Fig. 3. Highest weight gain $(\mathrm{g})$ in aquarium system was $2.42 \mathrm{~g}$ in $\mathrm{T} 1$ and lowest weight gain $(\mathrm{g})$ was $1.03 \mathrm{~g}$ in $\mathrm{T} 4$. Significant differences in weight gain in prawn were observed among the treatments. The value was significantly highest in T1 (2.42g) followed by T2, T3 and T4. In pond system, highest weight gain (g) was $3.63 \mathrm{~g}$ in $\mathrm{T} 1$ and lowest weight gain $(\mathrm{g})$ was $2.96 \mathrm{~g}$ in T4. Here also significant differences were found among the treatments. The values were significantly high in T1 (3.63g) followed by T2 and T3. Hossain et al. (2000) reported that growth rate of $M$. rosenbergii was higher when fed Saudi-Bangla Shrimp diet (starter and grower) which matches the result of present study.

Table 5. Growth and food utilization of prawn fed different experimental diets in pond system

\begin{tabular}{ccccc}
\hline Parameters & Diet 1 & Diet 2 & Diet 3 & Diet 4 \\
\hline Mean initial weight(g) & $1.14 \pm 0.14$ & $1.19 \pm 0.12$ & $1.15 \pm 0.13$ & $1.19 \pm 0.14$ \\
Mean final weight(g) & $4.77 \pm 0.07$ & $4.69 \pm 0.12$ & $4.06 \pm 0.20$ & $3.88 \pm 0.16$ \\
Weight gain (g) & $3.63 \pm 0.07$ & $3.5 \pm 0.12$ & $2.91 \pm 0.20$ & $2.69 \pm 0.16$ \\
\% Weight gain & 318.42 & 294.11 & 253.04 & 226.05 \\
SGR (\% Day) & 2.39 & 2.29 & 2.10 & 1.96 \\
Survival rate (\%) & $78 \%$ & $72 \%$ & $64 \%$ & $66 \%$ \\
\hline
\end{tabular}

(*Figure in the parentheses indicates mean values \pm standard deviation)

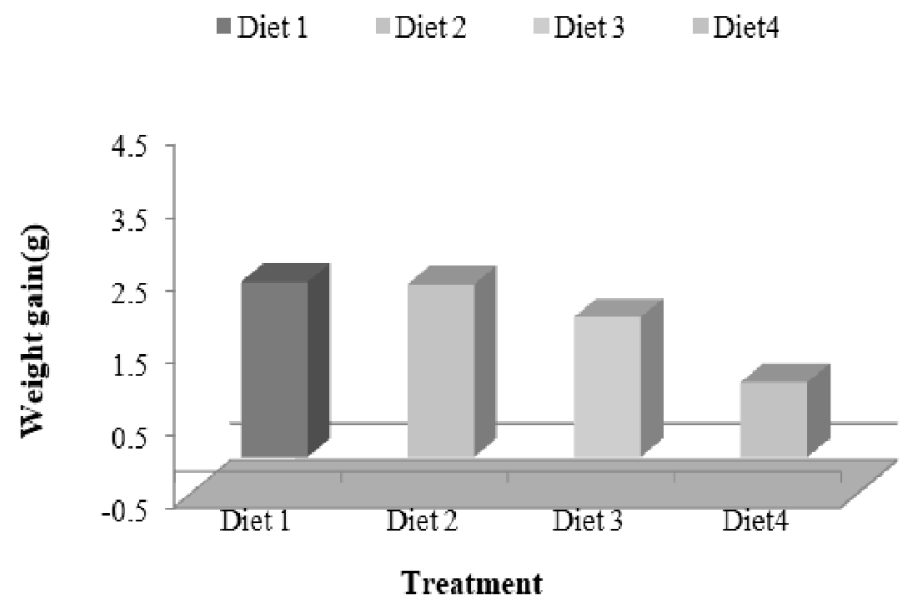

Fig. 2. Comparison of weight gain (g) of prawn (M. rosenbergii) in different treatments in aquarium system during the experimental period 


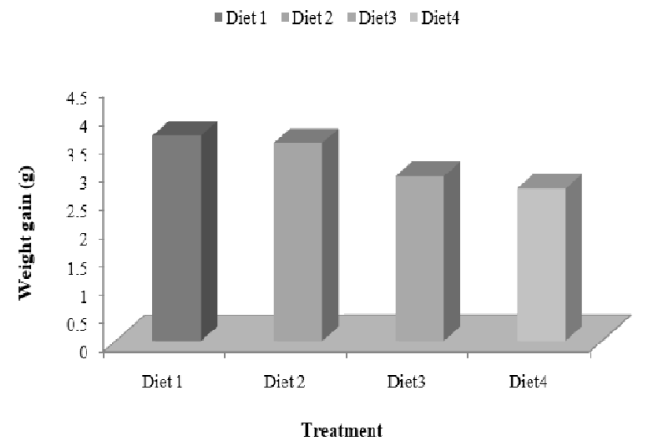

Fig. 3. Comparison of weight gain $(\mathrm{g})$ of $M$. rosenbergii in different treatments of pond system during the experimental period

\section{Percent weight gain}

The Percent weight gain of prawn in different treatments of aquarium system ranged between 81.74 to $195.90 \%$ (Table 4 and Fig. 4). The highest percent weight gain was obtained in prawn for Diet-2. The percent weight gain in prawn fed Diets 2, 3, and 4 (control) significantly differed with each other.
Comparisons in percent weight gain for different treatments in pond systems are graphically presented in Fig. 5. Here, highest percent weight gain was 318.42 in $\mathrm{T} 1$ and the lowest percent weight gain was found 226.0 in T4. There were significant differences among all the four treatments.

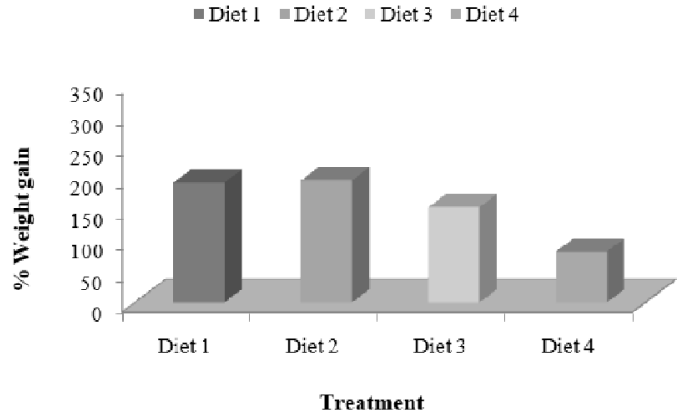

Fig. 4. Comparison of percent weight gain of prawn (M. rosenbergii) in different treatments of aquarium system during the experimental period

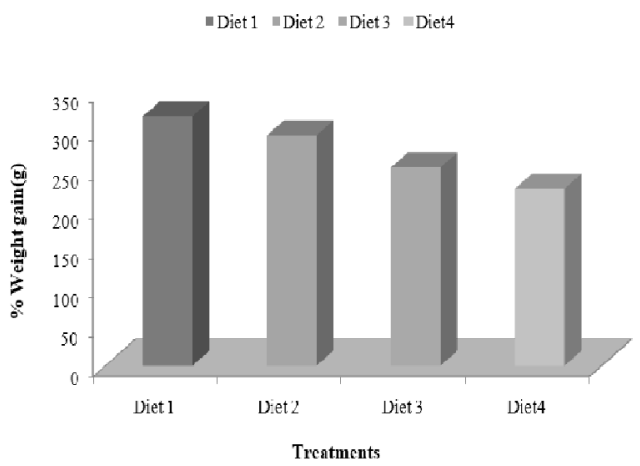

Fig. 5. Comparison of percent weight gain of prawn (M. rosenbergii) in different treatments of pond system during the experimental period 


\section{Specific growth rate (\% per day)}

The specific growth rate SGR (\% per day) of prawn in different treatments of aquarium system ranged between 0.99 to $1.80 \%$ (Table 4). The significantly highest SGR value was obtained in prawn for Diet-2. There was significant differences among the SGR value of prawns fed Diets 2, 3, and 4 (control). A comparison of SGR value among different treatments is graphically presented in Fig. 6. On the other hand, in pond system, the specific growth rate SGR (\% per day) of prawn in different treatments ranged between 1.96 to $2.39 \%$ (Table 5). Here, the highest SGR value was obtained in prawn $f$ or Diet-1. Here also significant differences among the SGR value of prawns fed Diets 2, 3, and 4 (control) were observed. A comparison of SGR value among different treatments in pond system is graphically shown in Fig. 7. Hossain et al. (2000) reported the higher SGR (\% per day) value in prawn (M. rosenbergii) while fed Saudi-Bangla Shrimp diet (starter and grower) and diet 1 containing 32\% protein. Du-Li (2002) reported higher SGR (\% per day) value when prawn fed diet containing $40 \%$ protein compared with $20 \%$ and $30 \%$ protein group. This finding coincides well with result obtained in the present study.

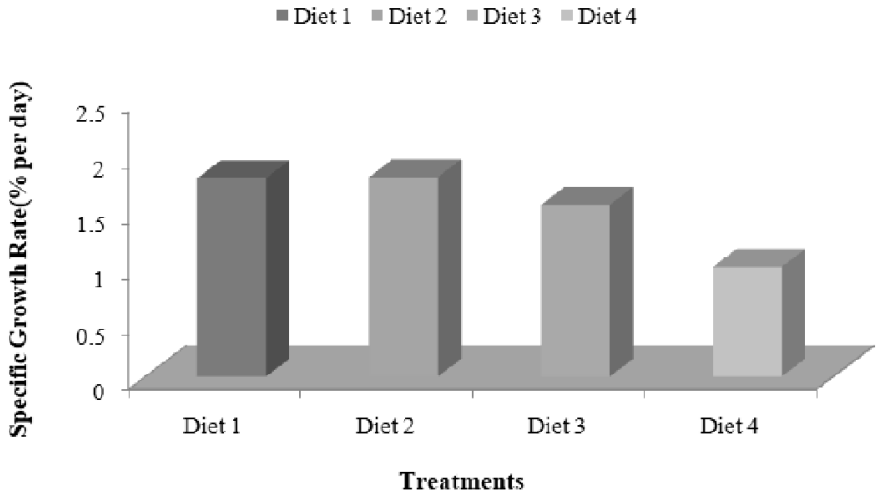

Fig. 6. Comparison of specific growth rate (\% per day) of prawn (M. rosenbergii) in different treatments of aquarium system during the experimental period

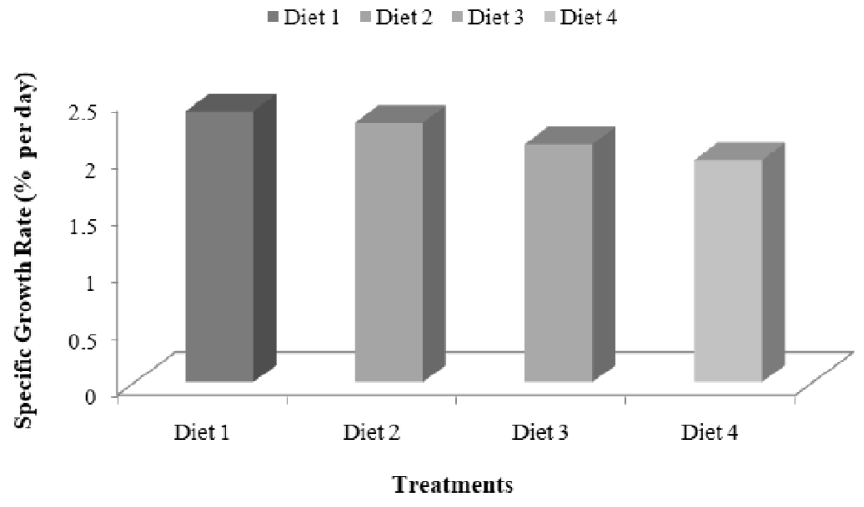

Fig. 7. Comparison of specific growth rate (\% per day) of prawn (M. rosenbergii) in different treatments of pond system during the experimental period

\section{Survival rate (\%)}

The survival rate $(\%)$ of prawn in different treatments of aquarium system was estimated after total harvesting of prawn by draining out of water from the aquaria and the ponds. The survival rate $(\%)$ of prawns varied between 70 to $80 \%$ (Table 4) in aquarium system. The highest survival rate $(\%)$ was found in prawn fed Diet-1 and the lowest for Diet-3. However, there were no significant differences among the survival rate (\%) of prawn fed Diets 1,2 and 4. A comparison of the survival rate $(\%)$ of prawns in different treatments is graphically shown in Fig. 8. In pond system, the survival rate $(\%)$ of prawn in different treatments varied between 64 to $78 \%$ (Table $5)$. The highest survival rate (\%) was observed in prawn fed Diet-1 and the lowest in Diet-3. However, there were no significant differences among the survival rate (\%) of prawn fed Diets 1, 2, 3 and 4. Here the 
comparison of the survival rate (\%) of prawns in different treatments is graphically presented in Fig. 9.

D`Abroma et al. (1989) noted that survival rate of prawn (M. rosenbergii) in earthen ponds ranged from $54.3 \%$ to $89 \%$. Siddiqui and Al-Hinty (1993) reported that the survival rate of freshwater prawn ( $M$. rosenbergii) varied from 71 to $93 \%$. Chand et al. (2000) stated that survival rate of freshwater prawn in ponds ranged from 49 to $54 \%$. Daniels et al. (1995) reported that survival rate of freshwater prawn ranged from 73.7 to $81.9 \%$ in earthen ponds fed a specially formulated diet. In the present study, survival rate was higher than the above studies, which might be because of aerators used in the experimental ponds during night and water exchanged at regular intervals. The better water quality might have positively contributed to the higher survival $(\%)$ of the prawns. Here, prawn fed Diets 1 and 2 attained the higher weight gain.

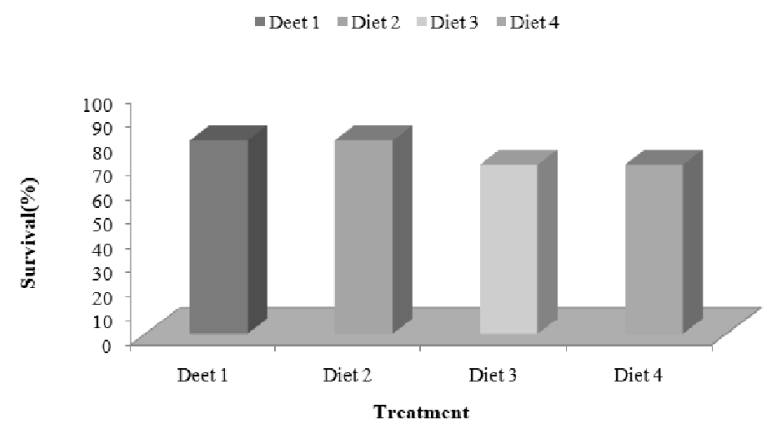

Fig. 8. Comparison of survival rate (\%) of prawn (M. rosenbergii) in different treatments of aquarium system during the experimental period

$\because$ Diet $1 \backsim \operatorname{Diet} 2 \backsim \operatorname{Diet} 3 \backsim \operatorname{Diet} 4$

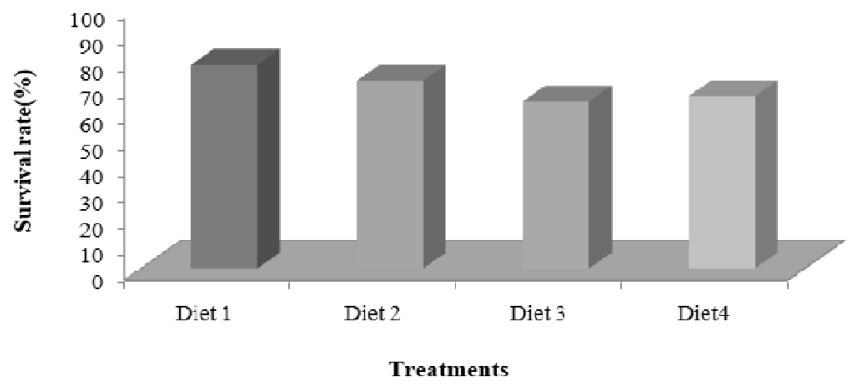

Fig. 9. Comparison of survival rate (\%) of prawn (M. rosenbergii) in different treatments of pond system during the experimental period

\section{Conclusion}

Considering the growth performance, survival rate $(\%)$, the best result was obtained with Diet 1 and diet 2 in the present study. Thus Diet-1 containing shrimp waste $35 \%$, rice bran $20 \%$, wheat bran $10 \%$, soy bean $15 \%$, molasses $4 \%$ and vitamin mineral premix may be recommended as a suitable diet for monoculture of $M$. rosenbergii in ponds.

\section{Acknowledgement}

The study was done with the financial support of Ministry of Science and Technology, Peopleôs Republic of Bangladesh.

\section{References}

AOAC 2005. Official Methods of Analysis. Association of Official Analytical Chemists International, 18th edition, Washington (D. C.).

Aranyakananda, P., Lawrence, A. L. 1993. Dietary protein and energy requirements of the whitelegged shrimp (Penaus vannamei), and the optimal protein to energy ratio, from Discovery to Commercialization, European Aquaculture Society, Oostende, Belgium. pp. 21.

Chand, B. K., Patra, B.C., Das, S. K. 2000. Effect of stocking density on harvest size of giant fresh 
water prawn (M. rosenbergii). Indian Journal of Animal Health, 40: 45-50.

Cousin, M., Cuzon, G., Blanched, E., Ruelle, R. 1991. Protein requirements following an optimum dietary energy to protein ratio for Penaeus vannamei juvenile, Institute National de la Recherche Agronomique, Paris, France. pp. 599-606.

DôAbramo, L. R., Heinen, J. H., Robinette, H. R., Collins, J. S. 1989. Production of the giant freshwater prawn $M$. rosenbergii stocked as juvenile at different densities in temperate zone ponds. Journal of World Aquaculture Society 20 (2): 81-89.

Daniels, W. H, D`Abramo, L. R., Fonderen, M. W., Martin, D.D. 1995. Effect of stocking density and feed on pond production characteristics and revenue of harvest freshwater prawns $M$. rosenbergii stocked as size-Graded juvenile. Journal of World Aquaculture Society 26(1): 38-47.

Du-Li, C., Niu, L. D,. Niu, C. J. 2002. Effects of dietary protein level on bioenergetics of the giant freshwater prawn, Macrobrachium rosenbergii (de Man) Crustaceana. 75: 875889.

Fair, P. H., Forter, A. R. 1981. The role of formulated feeds on natural productivity in culture of the prawn Macrobrachium rosenbergii Aquaculture 24: 233-243.

Hoq, M. E., Islam, M. M., Hossain, M. H. 1996. Polyculture of freshwater prawn (Macrobrachium rosenbergii) with Chinese and Indian carps in farmer's pond. Journal of Aquaculture in the Tropics 11:135-141.

Hossain, M. A., Siddique, M. A. L., Miaje, M. A. H. 2000: Development of low-cost feed for culture of giant freshwater prawn (Macrobrachium rosenbergii de Man) in ponds. Bangladesh Journal of Fisheries Resource 4(2): 127-134.

Jaruvat, N., Somnuk, K. 1987. Comparison of oxygen consumption between ablated and unsalted eye stalks of the tiger shrimp (Penaeus monodon) fabricus, Brackish water station, Rayong, Thailand, Department of Fisheries, Ministry of Agriculture Technical paper 13: 53.

Jia-Mo, P., Zhi-Guo, Y. L., Zi-Hao, L. E., Martinez ï Silva, Osorio-Dualiby, D, Torres-Virviescas, M. 1988. The intensive culture of freshwater prawn Macrobrachium rosenbergii (de Man), In: TRIANEA 1: 45-55.
Kanazawa, A., Teshima, S., Sasaki, M. 1984. Requirements of Juvenile prawn for calcium, phosphorus, magnesium, potassium, copper, manganese and iron. Memoirs of Faculty of Fisheries Kagoshima University, 33: 63-71.

Moor, A. B., Eitenmiller, R. R. 1980. Shrimp qualityBiological and Technological relationship, Research Bulletin 152: 75.

Sheen, S. S., Chen, S. J. 1992. Optimum dietary lipid requirement level of the tiger prawns (Penaeus monodon). In: Aquaculture 92: Growing Towards the $21^{\text {st }}$ Century (Abstract), Orlando, Florida. pp. 203.

Siddiqui, A. Q, Al-Hinty, H. M. 1993. Feasibility of freshwater prawn. Macrobrachium rosenbergii culture in the central region of Saudi Arabia, Effect of density on growth, yield and population structure, Proceeding of the first international symposium on aquaculture technology and investment opportunities, Ministry of Agriculture and Water, Riyadh, Saudi Arabia. pp. 304-329.

Swingle, H. S. 1967. Standardization of chemical analysis for waters and pond muds, FAO Fisheries Research, 4(4): 379-412. 